\title{
Mutual and Non-exclusive: Food Security as key to National Security (Nigeria as a Case Study)
}

\author{
Yiolokun Isaac Babatunde \\ Department of History and Diplomatic Studies, Faculty of Humanities, Management and Social Sciences, \\ Federal University, Wukari, Taraba State, Nigeria
}

\begin{abstract}
At different times factors correlating with broad concepts on socio-political, economic and religious issues have either been singled out or combined as largely responsible for implosion in a polity. Within the mainstream of economic challenge, the less emphasized aspect of food insecurity serves a critical and complex causal factor vying for attention. Food security is seen in a broader concept of security and conceived as a public good in the same way defense and national sovereignty is viewed. In Nigeria where millions of people are lacking food and experience individual insecurity on a daily basis, they tend to resort to extreme and extraordinary behavior which affects socio-economic order and threatens national security. Drawing from the conceptual definition, the discourse focuses on understanding food security matters within the context of food availability and accessibility; it provides an overview of food crisis in Nigeria. The study takes cue from incidences of students' unrest, the Almajirai factor, the Niger Delta restiveness and the Area boys' syndrome Nigeria to articulate the opinion that food crisis and national insecurity are mutual and non-exclusive. It concludes that for the purpose of economic and moral arguments government should examine and direct food and agricultural policies towards programmes that will enhance food security in order to check anti social attitudes in Nigeria.
\end{abstract}

Keywords: crisis, food, extraordinary, policy, security

\section{Introduction}

Food is a basic human need without which life ceases. It relative importance as constituting the most essential ingredient in the survival of any community cannot be overemphasized. As a direct product of agriculture and a fundamental issue for national progress and human well being, governments all over the world pay primary attention to its food economy and by implication any government that neglects the agricultural sector of its economy is simply preparing the people for inevitable doom. $[1]^{1}$ It is unmistakably true that in most developing countries (agrarian societies) of the world, for instance Nigeria, agricultural productivity had or has been playing pivotal role in her economic growth and development.[2] Nigeria as a polity has continued to grapple with the challenge of nation-building and at different occasion put up security measures to safeguard it against every shade of potential violability. National security is a strategic project requiring visionary architects and those with sound constructive skill to put and maintain it as a solid structure. The food subsector as Idachaba noted represents the unappreciated pillar for the social stability of the nation, because where hunger exists, the affected populace would not hesitate to go on rioting.[3] Food security (insecurity) could be regarded as one of the strategic issues that have impact on the security of a nation and which should be accorded a position of prominence.

\section{Conceptual Definition and Issues}

According to World Bank and Food and Agriculture Organization (FAO) Agriculture Series publication of 1984, food security is defined as "access by all people at all times to enough food for an active and healthy life"[4]. This definition represents an orthodox perspective which could be regarded as less comprehensive. However, the International Food Policy Research Institute (IFPRI) and FAO publication of 2010 advanced a more comprehensive definition by describing food security as the condition in which all people, at all times, have physical, social and economic access to sufficient, safe and nutritious food that meets their dietary needs and food preferences for an active and healthy life.[5] This definition is a follow up to the one adopted at the 1996 World Food Summit held in Rome. The Summit held that food security exists when all people, at all times, have physical and economic access to sufficient, safe and nutritious food that meets their dietary needs and food preferences for an active and healthy life.

It is inferred therefore that food security relates to food availability and accessibility, stability of supply and the utilisation to meet both nutritional and psychological needs without which there would not have been a resultant effect of an active and healthy living. Beyond the physical availability of food, which could 
either be cultivated, imported or in form of aid, it should be accessible to all people regardless of their social class or status. According to Agbu and Oche, to have access to food implies either the ability to grow it, buy it, or obtain it through some form of social distribution system.[6] Accessibility to food is said to be influenced by market forces and the price of food as well as an individual's purchasing capability, which is related to employment and livelihood opportunities.[7] The interplay of these factors in relation to an individual's accessibility to food provided the basis for the close link between food security matters and poverty.[8] Therefore, one can arguably describe food security as a situation where food is made available and affordable for all people to consume for healthy living. Food insecurity on the other hand, exists when people do not have adequate physical, social and economic access to food.[9]

Food security exists at both micro and macro levels, which are, the households at one level and the nation at another level. The ability of households in rural and urban Nigeria to generate sufficient income, together with their own production, is crucial to meeting their food needs and attaining food security. At the national level, it reflects the capacity of a nation to procure enough food through production or imports to feed its population.[10] Food security is now seen as a concept under the broader concept of human security. For instance, those who possessed adequate and well stored farm produce like grain bins and yam barn subsist better than those who had less because the possession of these items gave man a feeling of security and wellbeing.[11] Thus, an adequate storage facilities or system as well as strategic food reserve matters are vital to the concept of food security.

In an interview granted by Jonathan Babatola, former director of NIHORT, he confidently compared "Agriculture" embodying food production with national security subject and thereby qualified it as a strategic policy issue of a state.[12] In a similar perspective, Ojetunji affirmed that "Food Security, in the historical, political, cultural, and economic contexts of post-colonial Africa, must be conceived as a public good, in the same way as defense and national sovereignty"[13].

It could be deduced from above that apart from the strategic importance, food security has influence on virtually all spheres of life and reflects a natural crave that people have for food satisfaction which could be compared to their natural reaction or instinct when faced with a violation of their territorial integrity. Jonathan Shrier's view is also tailored to that perspective. While making a comparative assessment between national security and food security, he metaphorically asserted that where "natural security" often conjures up images of missiles and militaries, it should also prompt the images of maize and millet.[14] This assertion brings to the fore the exigency of according equal status to food and agriculture matters in the same manner as defense matters. The priority given to the issue of national security is reflected in the huge budgetary allocation earmarked for the defense ministry by successive administrations in Nigeria in its fiscal planning. It is contended that agriculture, the hub of food security should be accorded a fair share of the budgetary allocation just as the Food and Agricultural Organisation's (FAO's) standard for every government is to fund agriculture with 25 per cent of the country's budget. This is considered against the backdrop of the fact that both defense and food intake carries the survival instinct.

Food insecurity has in its wake, attendant implications such as food crisis, hunger, poverty and other forms of miseries. In such a polity where food insufficiency prevails, sovereignty of that entity could be endangered. Hunger could trigger conflict when people feel they have nothing more to lose and so are willing to fight for resources, political power, and cultural respect. Throughout recorded history, riots and rebellions have occurred in towns and cities when the populace experienced or feared food shortages. For instance, the discontent among Parisians and other urban folk over rising food prices and the inadequate government response played a key role in sparking the French revolution of 1789 leading to the overthrow of the hitherto existing order.[15] In Central America, incidents of human right abuse, the quest for land acquisition, call for social justice and democratic institution occasioned by protracted food crises have led to outbreak of civil wars.[16]

Food security is also linked to Bio-technology- modern technology of food production and processing based on Genetically Modified (GMO) hormones and other growth promoters). The emphasis of this perspective is based on food safety. According to Radha Gopalan,[17] food security entails the capacity to provide safe and adequate food to the population with the consideration of the ecosystem. In other words, the natural resources, environment and the quality of life must not be compromised so that food production can be made available in a safe and sustained manner. Similarly, Awele Odor, described food security as a strategic deceit.[18] He shared Gopalan's view that food security should be equated with food safety, but disagreed with Gopalan on the concept of GMO as a safety measure which he denounced as generally toxic, allergenic and containing less nutrients. He was of the opinion that GMO has the capacity to lead to various diseases such as cancer, diabetes, liver, heart, lung or immune system breakdown. He thus, discounted the whole essence of food security as a failure and a deceit. According to him, a food contributor that uses bio-technology in food production seeks commercial ends and not for developmental purpose. 
These conceptual issues suggest the interwoven or complex analyses of what constitutes food security. However, this paper does not intend to be entangled in the intricacies of the definition or a term involved but is much more concern with the perspective in which food availability, accessibility, stability of supply and utilization has been instrumental in promoting national security or ensuring the corporate existence of the state. With the emphasis that food insecurity, in terms of lack of physical, social and economic access to adequate and stable food supply makes people to be vulnerable and predisposed them to cause destabilization within the state.

\section{An Overview of Food Crisis or Insecurity in Nigeria}

Orville Freeman, a former United State Secretary of Agriculture, captures the state of food and man over time in a succinct manner as follows:

Since the beginning of time, man experienced food shortage, hunger, and starvation...today the future of our entire civilization in an interdependent world is threatened...[19]

The assertion brings to the fore the allegation that the global society has been grappling with food insufficiency and at different times, nations have had to come together to assist certain other nations ravaged with famine or food shortage. This global crisis of food insecurity has been considered to be almost intractable.[20]

It is paradoxical to note that Nigeria has continued to experience food crisis, in spite of the enormous potentials and capability of the sector not only in providing sufficient food over and above the national food need, but also solving the problems of unemployment and poverty in the country.[21] Interestingly, up to the first decade of Nigeria's independence, the agricultural sector constituted the bulk of its economy, served as the major foreign exchange earner being a net exporter of food and cash crops and indeed there was no food crisis. [22]

However, this is not to suggest that there were no reported cases of food shortages or scarcity prior to the decades before independence. The Aba Women Riot of 1929 bored a connotation of reactions and protests over the state of food insecurity due to the increased taxation which led to high food price. According to Gloria Chukwu, the Igbo and Ibibio women conceived the activities of the British colonialists and their collaboratorsWarrant chiefs as an act of imposition of unpopular policy which entailed taxation, high price of import commodities and low cost of export crops. [23] The women vehemently opposed the economic measures as a result of the fact that such fiscal policies had implication on their food consumption pattern, hence, resulting into food insecurity. A former Permanent Secretary, Ministry of Agriculture, alleged that perhaps the first time that Nigeria experienced food problem was during the Second World War (1939-1945) when agricultural activities declined owing to war disruption, although, he maintained that the situation was not prolonged as to degenerate into a crisis.[24] Food scarcity reappeared during the Civil War (1967-1970) in Nigeria, but it was alleged to be of mild proportion and a transitory phenomenon.[25]

Food problem in Nigeria became an apparent developmental issue or a crisis following the latent impact of the Civil War on agricultural production; the drought of 1972-74 that led to the massive loss of crops and livestock; the incidence of the prevailing massive oil exploration in the Niger Delta area in the 1970s amongst others. A graphic detail of the Nigerian Food crisis was encapsulated in the analysis made by M.O. Ojo thus:

Nigeria witnessed the first signs of a food problem during the Civil War when agriculture was neglected and food imports as well as other types of imports, were deliberately curtailed to save resources for survival...the food situation were compounded by occurrence of the Sahelian drought which adversely affected food production...the beginning of serious food crisis was in 1974-1975, the period in which windfall gains in crude oil export earnings were monetizes to expand government and personal incomes significantly. Without clear strategy for the effective utilization of the part of the available resources for the transformation of the agriculture sector.[26]

These arguments find support from a number of literatures on food and agricultural discourse.[27] There was the perception that beginning from the 1970s to the 1980s, Nigeria transited from a food secured to a food unsecured country.[28]

As suggested above, the second decade of the post-independence (1970-1980) witnessed a considerable state of worry in the increase in food problem and a widening supply-demand gap as a result of a relatively high rate of growth which was about 3.5 per cent per annum in food demand and a lagging rate of growth which was about 1.5 percent per annum in production.[29] The reasons adduced to the increase in demand were the high rates in which the population soared, the per capita real income and urbanization derived from high rate of rural-urban drift while on the production side, some of the challenges witnessed resulted from farm resource constraints particularly as touching the use of labour and the availability of capital, low technology inputs, poor storage and marketing facilities and the past underfunding of the agricultural sector in the development planning.[30] Corroborating this position, Bamisaye added that the food crisis deepened not just because of the rapidly increasing food import bills, high cost and even scarcity of staple food items but also in the decay of the rural areas and massive migration of rural producers to the urban centres.[31] 
The food crisis in Nigeria in the opinion of Ayoola, could be situated within the context of agricultural economy which he attributed to two major factors- technology and policy[32] He described the agricultural sector of Nigeria as that which is operated on low technology where it becomes difficult to transform production activities from it low level of efficiency to the higher level where proper utilization of inputs could guarantee increased production. On policy, he faulted the market system where economic liberalism policy allowed for external bodies like the multinational corporations and the presence of externalities whose objectives for agricultural production do not necessarily tally the indigenous developmental needs and aspirations.[33] The Udoji Commission of 1974 set up to consider the issue of wages of civil servants resulted in a generalized salary increase which intricately contributed to the rising food price and the rate of import of the second decade of independence.[34] The concession of the Gowon administration to the recommendations of the Commission led to increase in real income of the urban settlers mostly those within government circle or payroll occasioning the introduction of inflation among other malaise. The development was said to brew disaffection within the inner circle of the administration culminating in the eventual overthrown of that regime.[35] The consequence of the role of the Commission was adjudged to be a curse rather than be a blessing to the workers.[36]

\section{The Mutual Relationship: Food and National Security}

The mutual relationship between these two key concepts is streamlined along the outcome of the vigorous criticism that trailed the realist state-centric notion of national security in the early 1990s. Critics averred that rather than the state, the safety of human beings should be of topmost concern in global security matters. This position gave way to the re-prioritization of human security over and above state security within the broad based concept of security. Subsequently, the phenomenon of human safety and development became an overriding force in determining the projection of sustainable development programs. It is contended in this writing that food security- the art of making food items readily available and accessible to the people holds sway within the mainstream economic processes and leads to both human and state security, whereas, the neglect or de-emphasis of food security arguably could pose grave danger to human values, and by and large has consequences for national security.

Regardless of its causal factor, food insecurity epitomizes hunger and could trigger instability. The mutuality of food security and national security in this context strongly projects in an exclusive manner, the inherent capacity for inbuilt stability within a polity as a result of food availability and accessibility. In a contributory remarks to the issues of food and national security, U.S. Vice President, Joe Biden clarifies that when resources are committed to ward off food insecurity and prevent its recurrence, such measures would prevent the vicious cycles of rising extremism, armed conflict, state failure that can require far larger commitments of resources down the road.[37]

Certain institutions of higher learning in Nigeria have witnessed situation where students went on rampage resulting into breakdown of law and order over what seemed or was perceived to be shoddy institutional food policy arrangement which led to denial of access to either quantitative or qualitative food supply. For instance, the students of Ahmadu Bello University in 1981 protested over the issue of rice shortage, a staple food of students on campus. The same was reported of their counterparts in the University of Ibadan who went on demonstration for poor feeding services in the institution while in 1979 students of Usman dan Fodio University as a result of inadequate food consumption went on rampage which led to the death of two students[38] Had the spate of the students' demonstration and rioting not met with immediate response from law enforcement agencies, it would have engulfed all other institutions of higher learning and caused nationwide instability.

The often heard expression that a hungry man is an angry man and the syndrome of man must wak is typical of the numerous sayings and slangs that reflect the condition of a frustrated and desperate mind. Implicit in these expressions is the susceptibility of the affected person to resort to some unwholesome behaviour or means to satisfy his physiological needs. In a similar vein, underfed or hungry individuals could offer little or no resistance or be tolerance in exercising emotional stability in a face of extreme hunger. In other words, individual(s) who suffer from hunger are more prone to take to anti-social vices, or resort to extraordinary behavior or irrational manner. The activities of social miscreants or hoodlums who serve as pawns in the chess-game of the faceless manipulators have bearings with food security challenges. In some parts of northern Nigeria, these social urchins, beggars, scavengers, etc. when promised and surfeited with daily meals could be ordered to perpetrate heinous crimes such as arson, killing of innocent people and without unrestraint they act accordingly as directed. Some of these traits have found expression in the spate and intensity of the current national security challenge with regards to new phase of terrorism. Poverty, an index of food insecurity is more rampant in the region.[39] In this case, the activities of the Almajirai in Northern Nigeria require a brief explanation. 
The Almajirai in Hausaland refers to children sent from their homes and entrusted in the care of Islamic teachers for the purpose of acquiring Islamic knowledge, especially the teachings of the Holy Quran. According to Yahaya, the Almajiri who is thought to be a moral and conscientious pupil in search of knowledge suddenly becomes a menace in the society. For most of the times, he begs for food instead of concentrating on his studies and when he graduates, he turns into an itinerant beggar, wandering from one place to another without engaging in meaningful and productive economic activity.[40] These Almajirai lacked both physical and economic access to food supply which predisposed them as easy prey to political juggernauts and mischief makers. The involvement of the Almajirai in most of the major conflicts and violence witnessed in many towns and cities in the northern parts of Nigeria has resulted into large scale bloodlettings which continue to threaten the corporate existence of the polity. The resonance of violence in this part of the country as well is traced to the ubiquity of this elements.[41]

Similarly, Albert indicated that all government White Papers on the intractable ethno-religious crises in the north indicated the pauperized Almajirai as perpetrators of such violence.[42] They formed the major recruits of riots which have reverberating effects across the nation, this is because their attack is usually targeted at non-indigenes in northern towns and cities.[43] In cosmopolitan cities or ethnic pluralistic northern cities like Kano, Kaduna, Jos, Maiduguri, and Zaria among others, the non-indigenes or settlers who invest their resources especially on sale of food items and consumables are mostly affected at the outbreak of violence. The store or building where food stuffs or products are kept to be sold becomes the prime target for miscreants who rely on the food products for consumption and survival during the crisis situation.[44] At some occasion, these street urchins orchestrate violence as smoke screens to loot food and consumables. In Nigeria where religion always serves as vortex of violence, it was suggested that religious leaders should in addition to spiritual food make provision for physical food as a sustaining panacea to the intransigent religious intolerance which constantly bring the country to the brink of collapse.[45]

While responding to an interview on the state of the Almajirai, Usman Jubrin, the President of National Council for the Welfare of the Destitute was of the opinion that the very essence that the Almajirai are destitute, and must beg to survive pushes them to a state of despondency and as much, makes them a real threat and problem to the state.[46] He further disclosed that it is only when the Federal government becomes responsive to the needs of the Almajirai that the children (Almajirai) would be prevented from taking over the machinery of government illegally and at a time least expected.[47] It is instructive to note that what was perceived as a blasphemous cartoon on Prophet Mohammed published by a Danish print media- Tylland Posten in September 2005 sparked a violent protest leading to a near conflagration as a result of killings, arson, looting among other criminalities in some northern towns and cities.[48] While the unidentified perpetrators were alleged to be miscreants, thugs and hoodlums, there was much reason to justify the presumption given the weight of the exposition by a cleric in Borno state in connection to identifying the perpetrators. Sheikh Mohammed Abba Aji asserted that on a daily basis trailer load of people was being brought to virtually all towns in the state from other parts of the country and in the trailer you will find one Mallam with 150 pupils under his care. He further said that it is not always the case that these Mallams understand the dictates of Islam. [49]

Given the possibility of exaggeration of the figures of the pupils or their ratio in relation to the Mallams, it is not unexpected that pupils that are no longer under parental care and without any definite assurance of steady food supply would become not only a burden to the Mallams but social menace to the society at large. Their pressure would be felt across the various towns and the region at large as a result of their spread. A graphic picture of the nature of destitution and poverty distribution in the geo-political zones of the north has it that, there is high number of school age children roaming the streets begging. The northern poverty index is rising astronomically without concrete efforts to curtail it. The poverty rate in the three geo-political zones of north-central, north -east and north- west are $65 \%, 70 \%$ and $77 \%$ respectively.[50]

From the trajectory provided, there is little to wonder why Northern Nigeria is more predisposed to internal social disorder as a result of its high rate of food unsecured population. The experience of food insecurity is not limited to the north alone, considering the fact that the fight against hunger is not geographically bounded, but rather a national affair with both moral and strategic imperatives.

Most of the contentions that have made the Niger Delta area become restive and in a state of conflict are as a result of the deterioration in the sustainability of livelihood systems and this border on the degradation of the environment or ecology which inadvertently made food and agricultural production less available and inaccessible. The Niger Delta area's food insecurity is aggravated by both Governmental, Non-governmental, and International Actors activities in the oil rich region. Okwechime remarked that the environmental pollution resulting from the spills, leaks, blowouts and gas flaring have degraded the local environment and ruined the economy to the extent that the traditional occupations of majority of the people which are farming and fishing have been rendered incapacitated.[51] The notion that the ability to grow food which Agbu and Oche considers as one of the indices of food security is germane to the issue of food accessibility and the Niger Delta crisis. To 
be deprived the use of natural gift of land for food production due to oil exploration activities remains a sore point in the agitations of the people of Niger Delta.

Despite the shortage of land for food production due to the poor terrain in the Niger Delta, there is increasing pressure from the oil industry for the use of the available arable land for construction of ancillary facilities such as flow stations, pipelines, roads, staff quarters just to mention a few have served to further compounded the inability to ensure food security in the Niger Delta and increased the miseries of the people. A 1996 report on Niger Delta Environment Survey revealed that Niger Delta had become a victim of agricultural decline/shortened fallow, biodiversity depletion, fisheries decline among other life threatening development[52] and have forced many youths taken to vices such as banditry, kidnapping, sabotage and other crimes capable of destabilizing the polity simply because they want to feed well.

It should also be understood that the destabilization of the oil rich region where the main resource of Nigeria's foreign exchange earnings is generated would definitely spell doom for the nation and international community that are benefiting from the trade relations would not be spared of the untoward effects.

In a related development, the activities of the so-called Area boys and girls constitute a peculiar development in this discourse. According to a study by the Nigerian branch of the UN Office on Drugs and Crime, the activities of the Area boys and girls in some parts of Western Nigeria, especially in Lagos is attributable to a complex dynamics of socio-economic deprivation confronting the young people in cities. This situation has been blamed to be part of the fallout of the existing pervasive poverty which has provided the platform for mischief makers to carry out nefarious activities and they serve as ready-made tool for the bouts of ethnic, religious and political violence that intermittently erupt in Lagos.[53] An area boy asserted thus:

"I indulged in fraud and other criminal activities in order to get money to buy food which I considered the most essential thing in life. Most times when I don't have money, I forced my way into a canteen, eat and escape. But when I am surfeited, I care less about making trouble" [54]

\section{Conclusion}

The Nigerian government has both economic and moral obligation to put to check the increasing rate of food insufficiency in the country. Chief Audu Ogbeh was vivid to assert that the country will continue to witness insecurity when all process hampering food production sustains and Nigerians remain hungry.[55] $\mathrm{He}$ attributed the incessant socio-political instability in Nigeria to the neglect of the agricultural sector. Similarly, Abdullahi Adamu lamented the tragic consequences of food insecurity and warned that peace will remain an illusion when our local food production continues to fail, while farmers were being displaced and hunger ravaged.[56]

The strength of Nigeria has been related to its abundant land, labour and natural resources which made her largely agrarian. As expected, a country with such potentials requires government intervention through sound policy directives to tailor these resources for the realization of food security. While some achievements were recorded, through the initiation and implementation of some agricultural and food policies and programmes, there were also weaknesses noticeable in the gap between the formulation and execution strategy. Some of the programnmes include: National Acceleration for Food Production Policy (NAFPP), Operation Feed the Nation (OFN), River Basin Development Authorities (RBDAs), Green Revolution (GR), Agricultural Development Programs (ADPs), Directorate for Food Road and Rural Infrastructure (DFRRI), and National Agricultural Land Development Authority (NALDA) among several others. The major impediment revolves around inconsistencies in stated principles or statement of actions intended to attain the objectives of food security. The failure of the Nigerian government to achieve food security within the mainstream of its macroeconomic objectives has posed serious challenge to national security. Put differently, the overarching effect of food crisis ultimately affects virtually all organic sector of the economy.

According to Idachaba,[57] food security must not be by proclamation, or at a rhetorical level, but should be real; there should be food on the tables of the ordinary Nigerians, and not just food security only for government leaders or bureaucrats, rather, it should be all embracing regardless of the social class of the citizen. In the execution of the Nigerian Civil War, 1967-1970, the cut of food supply to the Eastern region resulted in starvation and heavy loss of lives. Food was employed as strategy which in the long run made the secession attempt a failure. This is to underscore the use of food as an instrument to restore national unity.

In the pecking order of global human developmental pursuit food security issue is of utmost significance. The Millennium Development Goals (MDGs) gave priority to the reduction of extreme hunger as a principal target for the attainment of humanitarian, socio-economic and political advancement in the world especially in the developing countries. It sought to halve between 1990 and 2015, the proportion of people who suffer from hunger. Nigeria is not left out of the global train which inadvertently would reduce the upsurge of insecurity witnessed in the country. 


\section{Notes and References}

[1] Obafemi Awolowo, Voice of Reason, Selected Speeches, Vol. 1 (Akure: Fagbamigbe Publishers, 1981), p. 64. See also, Uche U. Okonkwo, "The African Food Revolution: An Historical Appraissal” Pakistan Journal of Social Science, Vol. 7, Issue 6 (2010), pp. 441-448 DOI: $10.3923 /$ pjssci.2010.441.448

[2] E. Sokari-George: "Planning in Nigeria: The Agricultural Base 1962-1968", GeoJournal, Famine in the Focus of Geography, Vol.14, No. 1(January 1987), p. 97

[3] Francis S. Idachaba, "Nigerian Agriculture and the Law of Unintended Consequences" Being a text of remarks delivered as Chairman, Newswatch Colloquium on Nigerian Agriculture and the Food Crisis, held at Protea Hotel, Megambo Close, Maryland Estate, Ikeja, Lagos, on $21^{\text {st }}$ July, 2009, p.4

[4] "The World Bank's Strategy for Reducing Poverty and Hunger. A Report to the Development Community" in Environmental Sustainable Development Studies and Monograph Series No.4 .The World Bank, Washington DC, March 1995. p 7.See also Foreword to "The State of Food and Agriculture 1983", FAO Agriculture Series No.16, by Edouard Saouma, Director-General, Food and Agriculture Organization, (FAO) (Rome, 1984)

[5] See I.O. Akinyele, "Ensuring Food and Nutrition Security in Rural Nigeria: An Assessment of the Challenge, Information Needs and Analytical Capacity" Nigeria Strategy Support Program (NSSP) Background Paper 007 of International Food Policy Research Institute (IFPRI), November 2009, p.4; "The State of Food Insecurity in the World: Addressing Food Insecurity in Protracted Crises" Food and Agriculture Organization (FAO) (Rome, 2010), p. 8.

[6] Osita Agbu and Ogaba Oche, "Human Security and the Niger-Delta Crisis: the Plight of Women and Children" in Akinjide Osuntokun and Victor Ukaogo (eds.) Niger-Delta: Politics of Despair, Deprivation and Desperation (Lagos: ICS Service Ltd.,2012), p.43

[7] EC-FAO "Food Security Concepts and Frameworks: Information for Action Programme" (FAO: Rome, 2008), pp. 4-5

[8] Ibid.,

[9] "The State of Food Insecurity in the World: Addressing Food Insecurity in Protracted Crises" Food and Agriculture Organization (FAO) (Rome, 2010), p. 8

[10] A.A. Adebayo, "Food Security Status in Nigeria: Pre and Post Economic Deregulation Review" in International Journal of Economic Development Research and Investment, Vol.1, No. 1. April 2010. p. 138

[11] R.J. Gavin and Wale Oyemakinde, “Economic Development in Nigeria Since 1800" in Obaro Ikime (ed) Groundwork of Nigerian History, (Nigeria: Heinemann Educational Books Plc) p.482

[12] Nigerian Tribune, "Food Sufficiency is a Defence Issue" $25^{\text {th }}$ October, 2004. An interview granted by Prof. Jonathan Babatola, Director, NIHORT.

[13] Ojetunji Aboyade, Some Missing Policy links in Nigerian Agricultural Development, National Concord, Thursday May 6, 1993, p. 22

[14] Jonathan Shrier, "Food Security Contributes to National Security" posted October 28, 2011 http://blogs.state.gov/index.php/site/entry/food national security/ 20/03/2013. Accessed 2:56pm

[15] G. Lefebvre, The French Revolution (New York: Columbia University Press, 1962). quoted in Marc J. Cohen and Per PinstrupAndersen, "Food Security and Conflict" Social Research: Food: Nature and Culture, vol. 66, no. 1, (spring 1999), p. 384

[16] Ibid.,

[17] Radha Gopalan, "Sustainable Food Production and Consumption: Agenda for Action", Economic and Political Weekly, Vol. 36 No. 14/15 (April, 14-20, 2001), p. 1207

[18] Prince Awele Odor, an Independent and Public Good Promoter, giving his own contributions to a round table on 'Towards Achieving Food Security in Nigeria' held at the Nigerian Institute of Advanced Legal Studies (NIALS), The University of Lagos, (August 16, 2011).

[19] Orville L. Freeman, World Without Hunger,(New York: Frederick A. Praeger Publishers, 1968), p.3

[20] S.O. Olayide,: "Food and Nutrition Crisis in Nigeria", (I.U.P., 1982), p.1

[21] O. Oluwasola, and S.R.A. Adewusi, "Food Security in Nigeria: The Way Forward" in O.C Adebooye et al (eds.), Food, Health and Environmental Issues in Developing Countries: The Nigerian Situation, (Germany, Bonn: Alexander von Humboldt Foundation, September, 2008 ), p. 451

[22] Ibid.,

[23] Gloria I. Chukwu, "Women and Nationalist Movement" in Toyin Falola (ed.) Africa, Vol. 4 (Durham: Carolina Academic Press, 2002), p. 119

[24] M.T. Liman, "In the Eightees" A Public Lecture by the Permanent Secretary, Federal Ministry of Agriculture, at Ahmadu Bello University, Zaria, 29 $9^{\text {th }}$ July, 1982, p. 4; See also V.M. Manyong, et al. Agriculture in Nigeria: Identifying Opportunities for Increased Commercialization and Investment..., p. 39

[25] Ibid.,

[26] M.O. Ojo, Food Policy and Economic Development in Nigeria, (Central Bank of Nigeria: Page Publisher Services Ltd., 1991$)$, p.8

[27] See Prabuddha Sanyal and Suresh Babu, Policy Benchmarking and Tracking in Agricultural Policy Environment in Nigeria, Nigeria Strategic Support Program Report No.5 (International Food Policy Research Institute, Abuja: February, 2010), p. 6; Manyong, et al. Agriculture in Nigeria: Identifying Opportunities for Increased Commercialization and Investment, ibid.; Also, Hans-Otto Sano, "The Political Economy of Food in Nigeria 1960-1982", (A Discussion on Peasants, State and World Economy) Research Report No. 65, p.10.; A.O. Bamisaye, The Politics of Food in Nigeria Since Independence, Paper presented at African Studies Association, $26^{\text {th }}$ Annual Meeting, Boston, U.S.A. (December 7-10, 1983), p. 4

[28] O. Oluwasola and S.R.A Adewusi, "Food Security in Nigeria: The Way Forward" in Adebooye.O.C. et al. (eds.), Food, Health and Environmental Issues in Developing Countries: The Nigerian Situation, p. 452

[29] M.T. Liman In the Eightees, p. 5

[30] Ibid.,

[31] Bamisaye, ibid

[32] Ayoola, "From Food Deficiency to Food Sufficiency: Strategies to Overcome the Food Crisis in Nigeria", being a Paper presented at the National Agricultural Workshop and Exhibition organized by the Imo State Agricultural Development Project, Owerri (Concorde Hotel), $13^{\text {th }}-15^{\text {th }}$ September, 1995. pp.6-7

[33] Ibid.,

[34] See, Hans-Otto Sano, "The Political Economy of Food in Nigeria 1960-1982",(A Discussion on Peasants, State and World Economy) Research Report No. 65, p. 30 and F.S. Idachaba, Good Intentions are not Enough (Collected Essays on Government and Nigerian Agriculture), The Agricultural Process, Vol.1, (Ibadan: University Press Plc, 2006), p. 257

[35] See, Hans-Otto Sano, "The Political Economy of Food in Nigeria 1960-1982”, p. 30 
[36] Wole Tokede, Solving the Food Crisis, Daily Times, June 1, 1989, p.11 (This article was credited to Tokede on Daily Times publication of June 13, 1989, p. 13)

[37] Jonathan Shrier, Food Security Contributes to National Security, October 28, 2011. http://blogs.state.gov/index.php/site/entry/food national security/20/03/2013 Accessed 2:56pm

[38] O.A. Bamisaye, Empirical Evaluation of Food Situation in Nigeria and its Implications on State Security (1993), p.13

[39] Abdulkareem Mohammed, The Paradox of Boko Haram (Moving Image Limited, 2012), p. 38

[40] Yahaya Suleiman, "The Almajirai and the Rights of the Child to Education Towards Sustainable Development in Nigeria", $A$ Book of Readings, Vol. 1(Minna: Niger State College of Education, 2004), p. 185

[41] See Olayemi Akinwumi, "Ethnic Militias and Violence" in Toyin Falola and Steven J. Salm (eds.) Nigerian Cities (N.J: Trenton, Africa World Press, Inc., 2004), p. 355

[42] See Olawale Albert, "Kano: Religious Fundamentalism and Violence" in George Herault et.al (eds.) Youth, Street Culture and Urban Violence in Africa (Ibadan: IFRA, 1997), p. 289

[43] See Olawale Albert, ibid.,: Yahaya Suleiman, ibid.,: and : 'Kano: Anarchists targets More Cities" Tell News Magazines, 29 October, 2001, p. 36

[44] This is based on the writer's observation as a living witness to certain crises in northern parts of the country.

[45] "Solving the Food Crisis" Daily Times, June 1, 1989, p. 11

[46] See Christian Purefoy, "Nigeria's Almajiri Children Learning a Life of Poverty and Violence" Cable News Network (CNN) January 8, 2000 or edition.cnn.com/2010.WORLD/Africa/01/07/Nigeria.children.radicalization/index.html. Accessed 07/05/2013 [47] Ibid.,

[48] Dogara J. Gwamna, "the Turning of Religious Intolerance in Nigeria: the External Connections" in David O. Ogungbile and Akintunde E. Akinade (eds.) Creativity and Change in Nigerian Christianity (Malthouse Press Ltd., 2010), p. 283. See also Sunday Sun, February 26, 2006, p.6

[49] ThisDay Newspaper, February 26, 2006, p.108

[50] Abdulkareem Mohammed, The Paradox of Boko Haram (Moving Image Limited, 2012), p. 38

[51] Iwebunor Okwechime, "Oil Multinationals and the Politics of Corporate Social Responsibility in the Niger Delta" in Akin Alao and Rotimi Taiwo (eds.) Perspectives on African Studies: Essays in Honour of Toyin Falola (Lincolm Europa, 2011), p.2

[52] Ekpo Udeme, The Niger-Delta and Oil Politics, (Lagos: International Energy Communication Ltd.,) p.14 cited in Osuntokun and Ukaogo (eds.) ibid.,p.44

[53] http://www.irinnews.org/report/55442/nigeria-area-boys-a-growing-menace-on-the-streets-of-lagos.

[54] Interview: Bodmas Babajide, (Area Boy) Age 23, 3, Nojimu Street, Moshalasi Bus Stop, Alagbado, 2:30pm

[55] Audu Ogbeh, "Insecurity will Continue if Nigerians Remain Hungry" in Daily Independence Newspaper, October 15, 2012. pp.1-2

[56] Senator Abdullahi Adamu, Chairman, Board of Trustees, National Agricultural Foundation of Nigerian (NAFN), "Agric Foundation Warns of Looming Food Shortage" The Nation Newspaper, Friday, October 12, 2012. p. XXII

[57] Idachaba, ibid., p.6 